\title{
Discrimination and Implicit Bias in a Racially Unequal Society
}

\author{
R. Richard Banks \\ Jennifer L. Eberhardt \\ Lee Ross $\dagger$
}

INTRODUCTION

For most of American history, racial discrimination was legally permissible and racial bias was openly espoused. African Americans, in particular, were regarded as inferior to Whites and subjected to the most rank forms of overt discrimination.

Now, our society seems to have developed a broad consensus in opposition to racial bias and to discrimination that burdens minorities, a consensus from which only extremists would openly depart. Discrimination is prohibited, as a matter of constitutional and statutory law, in a wide range of settings. Racism has been morally condemned and discredited. However much commentators may disagree about measures that benefit minorities, all join in opposing bias and discrimination.'

A considerable amount of current scholarship assesses the extent of bias and discrimination in contemporary society. How much bias remains in people's hearts and minds? Does discrimination continue to stunt the progress of African Americans? These questions gain urgency from the persistence of racial disparities that disadvantage African Americans in various domains, including the criminal justice system. Many social

Copyright $\bigcirc 2006$ California Law Review, Inc. California Law Revicw, Inc. (CLR) is a California nonprofit corporation. CLR and the authors are solely responsible for the content of their publications.

$\dagger \quad$ The authors are all faculty members at Stanford University, Banks in the Law School, and Eberhardt and Ross in the Department of Psychology. The authors benefited greatly from the feedbaek offered at discussions at the University of Pennsylvania Law School and at the Center for Advanced Study in the Behavioral Sciences. Thanks as well to Christine Jolls, Mark Kelman, Dick Craswell, Carol Steiker, Kim Forde-Mazrui, Cecilia Ridgeway, Bob Weisberg, Ewart Thomas, and Laura Beny for extraordinarily useful eomments and conversations regarding earlier versions of this Article. Hilary Burbank Bergsicker, Su Jin Gatlin, Uchenna Ibekwe, Mchdi Miremadi, Renee Stowitzky, and Lori Wu provided excellent research and editorial support. The extraordinary patience of the editors of the California Law Review has been appreeiated during the long development of this Article.

1. A note about our terminology is in ordcr. Throughout this Article, the terms racial bias and racism are used interchangeably, as are Black and African American. When we refer to discrimination we mean discrimination that burdens historically disadvantaged racial minorities. 
scientists, social psychologists among them, have investigated the persistence of bias and discrimination in American society. ${ }^{2}$

In this Article, we consider two bodies of social psychological research, one relating to the criminal justice system in particular, and the other concerning racial bias generally. The criminal justice studies bear on issues of racial profiling, the use of lethal force, and criminal sentencing. These studies all find evidence that race continues to influence individuals' decisionmaking and behavior. The racial bias research centers on the Implicit Association Test (IAT), which aims to measure implicit bias that operates beyond individuals' conscious awareness, and may exist even among individuals who genuinely believe themselves to be unbiased. Consistent with the criminal justice studies, the IAT research has found that race continues to be psychologically salient.

While these bodies of research constitute valuable empirical evidence of the continuing significance of race, in this Article we use the studies to probe the nature of the consensus opposition to bias and discrimination. More specifically, we show that the ostensible consensus fractures as one moves from broad statements of principle to specific circumstances. The consensus splinters not so much because of support for bias and discrimination, but rather because there are multiple ways to conceptualize bias and to enact the antidiscrimination principle in the criminal justice context.

Consider the application of the antidiscrimination principle in the criminal justice context. It is often extraordinarily difficult to identify individual instances of discriminatory decisionmaking by, say, police officers, in part because of the discretion they exercise. Thus, claims about discrimination will tend to focus on racially disparate outcomes, which may be interpreted as evidence of discriminatory decisionmaking. Moreover, racial disparities may be perceived as unfair in their own right, even in the absence of discriminatory decisionmaking. In the criminal justice context, then, the antidiscrimination principle becomes somewhat akin to an equal treatment principle. ${ }^{3}$ Understood as equal treatment, however, the goal of nondiscrimination may be unrealizable. Equal treatment would mandate the removal of unjust disparities. But in a society as racially unequal as ours, in which Blacks and Whites are so dissimilarly situated, the

2. See, e.g., Confronting Racism: The Problem and the Response (Jennifer L. Eberhardt \& Susan T. Fiske eds., 1998); John F. Dovidio \& Samuel L. Gaertner, Aversive Racism, in 36 AdvancEs IN Experimental Social Psychology (M.P. Zanna ed., 2004); Susan T. Fiske, Stereotyping. Prejudice, and Discrimination, in 2 Handbook of Social Psychology 357 (Daniel T. Gilbert et al. eds., 4th ed. 1998); James M. Jones, Prejudice and Racism (1998); Prejudice, Discrimination, AND RaCisM (John F. Dovidio \& Samuel L. Gaertner eds., 1986).

3. Our eharacterization of antidiscrimination as equal treatment is meant to capture popular understanding of the antidiscrimination principle, in the criminal justiee context in particular. We are making no strong claim, either descriptive or normative, about the interpretation of the antidiscrimination principle, and are fully aware that any such argument would require much more elaboration tban we are able to provide here. 
elimination of one troublesome disparity will often give rise to another. Being fair to Black perpetrators of crime, to use the simplest example, might entail being unfair to Black victims of crime. In sum, then, enforcement of the antidiscrimination principle in the criminal justice context entails choosing among inequalities.

Pervasive racial inequality also complicates the question of what it would mean to be racially unbiased. According to the most straightforward account, to be racially unbiased would require one to accord race no more significance than, say, eye or hair color, and to act as though one does not notice race. But this understanding accords with neither our actual practices nor the ideals those practices embody. Our social practices and legal rules permit, indeed encourage, some species of race consciousness that virtually no one views as morally objectionable. Identifying racial bias, then, must entail deciding that some forms of race consciousness are more, or less, morally objectionable than others, a determination with respect to which reasonable minds may differ.

Recognizing the indeterminacy of our antidiscrimination and antibias ideals as they are applied in our racially unequal society yields a number of benefits. It encourages us to think more concretely about the meaning of racial equality. It draws attention to the interplay between legal ideals and social structure. It highlights the tradeoffs that enforcement of the nondiscrimination mandate may entail, and the substantive assessments that do, or at least should, inform that calculus. Ultimately, incorporating inequality into antidiscrimination analysis underscores the difficulty of the challenges we face in attempting to refashion the racial legacy of our past.

Part I presents the findings of studies that bear on the selection of individuals for investigation, the use of deadly force, and sentencing. Part II demonstrates the indeterminate meaning of the nondiscrimination mandate in the criminal justice context. Part III uses the IAT research to highlight the difficulty of defining racial bias.

\section{I \\ THE RESEARCH FINDINGS}

This Part reviews the findings from a number of studies that examine the potential influence of race with respect to investigative decisionmaking, the use of lethal force, and criminal sentencing. ${ }^{4}$ Racially disparate outcomes in each of these areas have prompted claims of discrimination and unfairness.

4. Consistent with the focus of the social psychological research, we focus on the case of African Americans. Of course, similar issues may arise with other groups. 


\section{A. Racial Profiling}

During the mid- to late-1990s, the disproportionate stopping and investigation of innocent racial minority motorists fueled substantial controversy about racial profiling by law enforcement officers. ${ }^{5}$ The issue of racial profiling is an obvious point of intersection between controversies about race, crime, and criminal justice on the one hand, and social psychological research on the other. Racial profiling is a form of stereotyping, ${ }^{6}$ which social psychologists have studied extensively. ${ }^{7}$ Psychologists have documented and explored the longstanding stereotype of African Americans as violent and prone to criminality. ${ }^{8}$ Indeed, this is the stereotype most commonly applied to Blacks- or at least to young Black males. ${ }^{9}$

In a recent series of experimental studies, Eberhardt and colleagues examined the psychological association between race and criminality. ${ }^{10}$ ln one study, they exposed police officers to a group of Black faces or a group of White faces and asked, "Who looks criminal?" "They found that police officers not only viewed more Black faces than White faces as criminal, but also viewed those Black faces rated as the most stereotypically Black (e.g., those faces with wide noses, thick lips, or dark skin) as the most criminal of all.

Eberhardt and colleagues also examined more directly how the stereotypic association between African Americans and criminality might operate in the context of racial profiling. Specifically, they investigated whether research participants would become more likely to visually attend to, or focus on, Black people when the participants were prompted, or more precisely primed, to think about crime. ${ }^{12}$ Eberhardt and colleagues found that both students and police officers, when they were primed to think about violent crime, became more likely to look at a Black face rather than a White face. ${ }^{13}$ Moreover, officers who were primed to think about violent

5. See R. Richard Banks, Beyond Profiling: Race, Policing, and the Drug War, 56 Stan. L. REV. 571 (2003).

6. A racial profile represents the belief that members of one racial group are more likely than members of another racial group to be involved in a particular type of criminal activity. See R. Richard Banks, Race-Based Suspect Selection and Color Blind Equal Protection Doctrine and Discourse, 48 UCLA L. REv. 1075 (2001).

7. For an overview of stereotyping research, see, e.g., Fiske, supra note 2, at 357.

8. Patricia G. Devine \& Andrew J. Elliot, Are Racial Stereotypes Really Fading? The Princeton Trilogy Revisited, 21 Personality \& Soc. Psychol. Bull. 1139 (1995).

9. Paul M. Sniderman \& Thomas Piazza, The Scar of Race $43-45$ (1993).

10. Jennifer L. Eberhardt et al., Seeing Black: Race, Crime, and Visual Processing, $87 \mathrm{~J}$. Personality \& Soc. Psychol. 876 (2004).

11. The faces were all of Stanford University students and staff, none of whom had any criminal history.

12. A priming manipulation is a widely used technique in experimental psychology studies that involves briefly presenting participants with a stimulus (e.g., a word or image) and subsequently with some other stimulus to which the participants must respond. The research aims to determine how the prime influences responses to the subsequent stimulus.

13. Eberhardt et al., supra note 10 , at $886-88$. 
crime and who misremembered a Black male image tended to recall that image as more stereotypically Black than it in fact was. ${ }^{14}$ Although one must be cautious in extending the findings of laboratory studies to real world settings, this research highlights the possibility that when officers are looking for wrongdoing, they may be inclined to look toward Blacks rather than Whites. Moreover, African Americans with a highly stereotypical Black appearance may be subject to the most scrutiny of all.

Perhaps surprisingly, Eberhardt and colleagues were unable to explain their results on the basis of individual differences in participants' levels of explicit racial bias. ${ }^{15}$ The researchers examined whether student participants' performance in the various aspects of the study were associated with their scores on conventional measures of racial bias, and did not find any statistically significant relationship. ${ }^{16}$

\section{B. Shooting Behavior}

The most contentious issue with respect to which law enforcement officers have been accused of racial stereotyping may be the use of force, particularly lethal force. Information compiled by the Bureau of Justice Statistics indicates that African Americans are four times more likely than Whites to die during, or as a result of, an encounter with a law enforcement officer. ${ }^{17}$ The most widely publicized case is that of Amadou Diallo, a West African immigrant shot to death by New York City police officers who believed, wrongly, that he was carrying a gun. ${ }^{18}$

The Diallo tragedy spurred a number of studies-conducted not only with university undergraduates but in some cases with community members and police officers as well-that have examined the potential

14. Id. at 881-83. The student participants did not complete a memory task.

15. Eberhardt and colleagues used the Modern Racism Scale and the Motivation to Control Prcjudiced Responding Scale as measures of explicit racial bias and bias control, respectivcly. Both are commonly used measures in social psychological studies. For discussion of the Modem Racism Scale, see John B. McConahay, et al., Has Racism Declined in America? It Depends on Who Is Asking and What Is Asked, 25 J. of Conflict Resolution 563 (1981). For discussion of the Motivation to Control Prejudice Measure, see Bridget C. Dunton \& Russell H. Fazio, An Individual Difference Measure of Motivation to Control Prejudiced Reactions, 23 Personality \& Soc. Psychol. Bull. 316 (1997).

16. Eberhardt ct. al., supra note 10 , at $880,884-85$. The researchers were unablc to obtain explicit prejudice measures for individual officers.

17. Jodi M. Brown \& Patrick A. Langan, U.S. Dep't of Justice, Bureau of Justicc Statistics, Policing and Homicide, 1976-98: Justifiable Homicide by Police, Police Officers Murdered by Felons 5 (Mar. 2001). The disproportion we refer to is judged against population figures and does not imply that African Americans who have violent encounters with the police are 4 times as likely to die as Whites who have violent encounters with the police.

18. Although the Diallo case has become popularly associated with racial profiling, the officers involved contended that they were searching for a rape suspect whose description Diallo allegcdly matched. Francie Latour, Protests Rise Over Diallo Verdict, Boston GloBe, Feb. 27, 2000, at A6; Tracey Tully \& John Marzulli, Feds Rip NYPD on Racial Bias, Cite Poor Defense vs. Profiling, N.Y. DAILY News, Apr. 28, 2000, at 8. 
influence of a suspect's race on a research participant's decision to "shoot" the suspect. ${ }^{19}$ Such studies generally use some form of video game simulation in which participants are presented with a series of images of Black or White men who are either "armed" (e.g., holding a gun) or "unarmed" (e.g., holding a wallet or cell phone), and instructed to "shoot" only if the "suspect" is "armed." 20

The shooting studies, conducted by several different groups of researchers, all found that shooting behavior differed based on the race of the "suspect." 21 One finding was that images of unarmed Black men were more likely to be "shot" than were images of unarmed White men, ${ }^{22}$ a result consistent with the shootings of unarmed Black men that have generated so much controversy. ${ }^{23}$ As with the racial profiling studies discussed above, the shooting behavior studies that tested for a correlation between shooting behavior and explicit racial bias did not find it. ${ }^{24}$ Shooting behavior did not

19. See, e.g., Joshua Correll et al., The Police Officer's Dilemma: Using Ethnicity to Disambiguate Potentially Threatening Individuals, 83 J. Personality \& Soc. Psychol. 1314 (2002); Anthony G. Greenwald et al., Targets of Discrimination: Effects of Race on Responses to Weapons Holders, 39 J. Experimental Soc. Psychol. 399 (2003); E. Ashby Plant \& B. Michelle Peruche, The Consequences of Race for Police Officers' Responses to Criminal Suspects, 16 PsYCHOL. SCI. 180 (2005); E. Ashby Plant et al., Eliminating Automatic Racial Bias: Making Race Non-Diagnostic For Responses to Criminal Suspects, 41 J. ExPERIMENTAL Soc. Psychol. 141 (2005).

20. In a related set of studies, participants were primed with either a Black or White face and asked to identify, as quickly as possible, whether an object displayed on a computer screen was a gun or a tool. B. Keith Payne, Prejudice and Perception: The Role of Automatic and Controlled Processes in Misperceiving a Weapon, 81 J. Personality \& Soc. Psychol. 181 (2001). See also Eberhardt et al., supra note 10; Charles M. Judd et al., Automatic Stereotypes vs. Automatic Prejudice: Sorting Out the Possibilities in the Payne (2001) Weapon Paradigm, 40 J. ExPerimental Soc. Psychol. 75 (2004).

21. See Correll et al., supra note 19, at 1325; Greenwald et al., supra note 19, at 403; Plant \& Peruche, supra note 19, at 182; Plant et al., supra note 19, at 153.

22. See, e.g., Correll et al., supra note 19, at 1325. More generally, participants made the fastest and most accurate decisions when deciding whether to shoot armed Black men and unarmed White men. See Greenwald et al., supra note 19, at 403; Correll et al., supra note 19, at 1320. As one research team concluded, " $[\mathrm{T}]$ he decision to shoot an armed target is made more quickly and more accurately if that target is African American than if he is White, whereas the decision not to shoot is made more quickly and accurately if the target is White." Correll et al., supra note 19, at 1320. While Plant and Peruche did find that police officers were more likely to mistakenly shoot an unarmed Black suspect than an unarmed White suspect, they tested for accuracy only, not for speed. See Plant \& Peruche, supra note 19 , at 181 .

23. See, e.g., Julian E. Barnes, Haitian-Americans March to Protest Brutality by Police, N. Y. TImes, Apr. 21, 2000, at B3; Francis X. Clines, Appeals for Peace in Ohio After Two Days of Protests, N. Y. Times, Apr. 12, 2001, at A 18; Bill Farrell, Gowanus Park Will Honor Teen, N.Y. DaILy News, July 18, 2001, at Suburban 1; The Patrick Dorismond Case, N. Y. TimEs, Mar. 21, 2000, at A22; Amy Waldman, Officer Charged with Misdemeanor Assault in Shooting of Teenager, N. Y. TIMEs, June 10, 2000 , at B3.

24. Correll, for example, after noting that participants who scored low in racial prejudice were just as likely to exhibit the shooter bias as participants who scored high in racial prejudice, concluded that shooting behavior "does not seem to simply reflect prejudice toward African Americans, and there is reason to believe the effect is present simply as a function of stereotypic associations that exist in our culture." Correll et al., supra note 19. Neither Plant and Peruche nor Plant et al. attempted any such correlation. The other studies found no correlation between shooting behavior and explicit bias. 
vary as a function of participants' scores on a conventional measure of racial bias.

\section{Sentencing Decisions}

There has been a great deal of empirical research concerning racial discrimination in sentencing, in particular capital sentencing. ${ }^{25}$ The most common finding of the capital sentencing research is that killers of White victims are more likely to be sentenced to death than are killers of Black victims. ${ }^{26}$ This finding holds even when statistically controlling for a wide variety of nonracial factors that may influence sentencing, and has been characterized by the United States General Accounting Office as "remarkably consistent across data sets, states, data collection methods, and analytic techniques." 27 A less consistent finding is that Black defendants are more likely than White defendants to be sentenced to death. ${ }^{28}$

Two recent studies have extended the sentencing discrimination research by examining what is arguably a more nuanced form of racial discrimination. Each study used actual sentencing data to investigate whether a stereotypically Black appearance is related to the severity of a defendant's criminal sentence. ${ }^{29}$ In one study, Eberhardt and colleagues presented the photographs of actual African American defendants convicted of murder and eligible for the death penalty to naïve participants who were asked to rate the racial stereotypicality of each face. ${ }^{30}$ The researchers

25. One of the leading empirical analysts of the death penalty is David Baldus. See, e.g., DAvID C. Baldus et al., Equal Justice and the Death Penalty: A legal and Empirical Analysis (1990); David C. Baldus et al., Comparative Review of Death Sentences: An Empirical Study of the Georgia Experience, 74 J. CRIM. L. \& CRIMINOLOGY 661 (1983); David C. Baldus et al,, Monitoring and Evaluating Contemporary Death Sentencing Systems: Lessons from Georgia, 18 U.C. DAvIS L. REv. 1375 (1985); David C. Baldus et al., Reflections on the "Inevitability" of Racial Discrimination in Capital Sentencing and the "Impossibility" of its Prevention, Detection, and Correction, 51 WASH. \& LeE L. Rev. 359 (1994); see also Samuel R. Gross \& Robert Mauro, Death and Discrimination: RaCial Disparities in Capital Sentencing (1989).

26. U.S. Gen. Acct. Off., Report to the Senate and House Committees on the Judiciary, Death Penalty Sentencing: Research Indicates Pattern of Racial Disparities (Feb. 1990).

27. Id.

28. David Baldus et al., Racial Discrimination and the Death Penalty in the Post-Furman Era: An Empirical and Legal Overview, with Recent Findings from Philadelphia, 83 CoRNELL L. REv. 1638 (1998).

29. See, e.g., Irene V. Blair et al., The Influence of Afrocentric Facial Features in Criminal Sentencing, 15 PSYCHOL. SCI. 674 (2004); Jennifer L. Eberhardt et al., Looking Deathworthy: Perceived Stereotypicality of Black Defendants Predicts Capital-Sentencing Outcomes, 17 PsYCHOL. SCI. 383 (2006); An interesting experimental study of discrimination in the sentencing of juvenile offenders is Sandra Graham \& Brian Lowery, Priming Unconscious Racial Stereotypes About Adolescent Offenders, 28 LAW \& Hum. Behav. 483 (2004).

30. Eberhardt et al., supra note 29. Drawing from a database of 600 death-eligible cases in Philadelphia that reached the penalty phase between 1979 and 1999, Eberhardt and colleagues asked study participants to rate, on a scale of 1 to 11 , how stereotypically Black each of 162 Black defendants appeared. The photographs included a randomly selected group of 118 defendants who had murdered Black victims, and the entire group of 44 Black defendants who had murdered White victims. The 
found that among African American defendants convicted of murdering White victims, death sentences were given to $58 \%$ of those rated as more stereotypically Black, but only to $24 \%$ of those rated as less stereotypically Black. This stereotypicality effect remained statistically significant even after controlling for defendant attractiveness and various other nonracial factors known to influence sentencing, including, for example, aggravating and mitigating circumstances, murder severity, defendant socioeconomic status, and victim socioeconomic status. ${ }^{31}$

In a similar study, ${ }^{32}$ Blair and colleagues had participants view the faces of Black and White prison inmates, ${ }^{33}$ and rate how stereotypically Black each face appeared relative to other members of the offender's racial group. ${ }^{34}$ While Blacks and Whites were given sentences of comparable length, ${ }^{35}$ "within each race, more Afrocentric features were associated with longer sentences, given equivalent criminal histories." 36 The researchers concluded that even when controlling for differences in criminal history, those defendants who possessed the most stereotypically Black facial features (relative to other members of their racial group) received, on average, sentences nearly eight months longer than those who possessed the least stereotypically Black features. ${ }^{37}$

These studies' use of actual sentencing data precludes any examination of whether sentencing decisions correlate with explicit bias. But both studies highlight a novel form of discrimination-racial stereotypicality discrimination-which has received substantial attention by social psychologists in recent years. ${ }^{38}$

participants who rated the faces neither knew the purpose of the study nor that the photographs depicted convicted murderers. Id. at 383-84.

31. Id. at 384 .

32. Blair et al., supra note 29.

33. The researchers randomly selected from the Florida Department of Corrections Database 216 male inmates whose trials took place during a three year period when sentencing laws were unchanged. Id. at 675 .

34. This comparison is an important aspect of their methodology. Faces were given stereotypicality ratings relative to other members of their group. Participants were asked to rate how stereotypically Black a Black person appeared relative to other Blacks, and how stereotypically Black a White person appeared relative to other Whites. Thus, ratings of Black stereotypicality cannot be readily compared across groups. Because offenders' stereotypical Blackness was rated relative to other members of their own racial group, White offenders were judged, in the aggregate, as no more stereotypically Black than Black offenders. $I d$.

35. The researchers found that "Black and White offenders, given equivalent criminal histories, were given roughly equivalent sentences." Id. at 677 .

36. Id. at 677 .

37. Blair, supra note 29 , at $674-79$.

38. See, e.g., lrene V. Blair et al., The Automaticity of Race and Afrocentric Facial Features, 87 J. Personality \& Soc. Psychol. 763 (2004); lrene V. Blair et al., The Role of Afrocentric Features in Person Perception: Judging by Features and Categories, 83 J. Personality \& Soc. Psychol. 25 (2002); lrene V. Blair et al., The Use of Afrocentric Features as Cues for Judgment in the Presence of Diagnostic Information, 35 EuR. J. Soc. PsychOL. 59 (2005); Eberhardt et al., supra note 10; Keith B. Maddox \& Stephanie A. Gray, Cognitive Representations of Black Americans: Reexploring the Role of 
The sorts of discrimination that these studies highlight-in the shooting of unarmed suspects, the investigation of innocent people, and criminal sentencing - may not be readily identifiable in specific cases. Efforts to eliminate such discrimination thus become efforts to eliminate racial disparities, which are taken as evidence of discrimination, and which may seem unfair in their own right.

As we will show, however, the effort to eliminate particular racial disparities in the domain of criminal justice is likely to produce other disparities, which might also be viewed as unfair. Such tradeoffs reflect the disproportionate numbers of African Americans in comparison to Whites among those who commit crime, are victimized by crime, and are incarcerated. ${ }^{39}$ Racial disparities in incarceration rates have worsened during the past few decades, even as absolute levels of imprisonment have increased for all groups. ${ }^{40}$ Between 1974 and 2001, the likelihood of entering prison increased for Black men more than for any other group. ${ }^{41}$ Young Black men are now more than seven times more likely than young White men to be incarcerated. ${ }^{42}$

African Americans both disproportionately commit and are victimized by violent crime. African Americans are nearly seven times more likely than Whites to be murdered, and approximately twice as likely to be robbed, raped, or sexually assaulted. ${ }^{43}$ Although less than $13 \%$ of the

Skin Tone, 28 Personality \& Soc. Psychol. Bull. 250 (2002); Keith B. Maddox \& Stephanie A. Gray, Manipulating Subcategory Salience: Exploring the Link Between Skin Tone and Social Perception of Blacks, 34 EuR. J. Soc. Psychol. 533 (2004).

39. The most provocative effort to situate increased incarceration rates in the context of racial inequality more generally was made by Loïc Wacquant. Loïc Wacquant, Deadly Symbiosis: When Ghetto and Prison Meet and Mesh, 3 Punishment \& Soc'y 95 (2000).

40. In 2002, the prison and jail population in the United States exceeded two million for the first time. See Paige Harrison \& Jennifer Karburg, Bureau of Justice Statistics, Prison and Jail Inmates at Midyear 2002 2, tbl.1 (2003).

41. Thomas P. Bonczar, U.S. Dept. of Justice, Prevalence of Imprisonment in the U.S. Population, 1974-2001, 5 (2003). The number of Black individuals in prison or on parole grew from $1,117,200$ in 1986 to $2,149,900$ in 1997. Bureau of Justice Statistics, Adults Under Correctional Supervision By Race 1986-97, available at http://www.ojp.usdoj.gov/bjs/glance/tables/cpracetab.htm (last visited May 19, 2006). For an earlier thoughtful analysis of racial trends in incarceration, see Alfred Blumstein, Racial Disproportionality of the U.S. Prison Populations Revisited, 64 U. CoLo. L. REv. 743 (1993).

42. According to recent data, Black men ages twenty-five to twenty-nine are 7.6 times more likely to be in prison than White men of the same age group. Paige M. Harrison \& Allen J. Beck, Bureau of Justice Statistics, Prison and Jail lnmates at Midyear 11 (2005). Black women are 4.4 times more likely than White women to entcr prison. Id. Black men are more than 6.9 times more likely than their White peers to enter prison. Id. at 11, tbl.14. Among Black men born between 1965 and 1969, $30 \%$ without a college education and $60 \%$ of those who dropped out of high school had been in prison by 1999. Becky Pettit \& Bruce Western, Mass Imprisonment and the Life Course: Race and Class Inequality in U.S. Incarceration, 69 AM. Soc. REv. 151 (2004).

43. More precisely, African Americans are 6.8 times as likely as Whites to be murdered, twice as likely to be robbed, and 2.1 times as likely to be raped or sexually assaulted. These ratios were calculated based on information contained in Shannan M. Catalano, Bureau of Justice Statistics, Criminal Victimization 2004 7, tb1.6 (2005). 
country's population, ${ }^{44}$ African Americans commit approximately half of murders and robberies, and one-third of assaults and rapes. ${ }^{45}$ Even for drug crimes, where it is extraordinarily difficult to determine the race of offenders (as opposed simply to the race of those arrested or convicted), the best available evidence is consistent with the disproportionate involvement of African Americans in the drug trade, either as regular users of hard drugs or, especially, as drug dealers. ${ }^{46}$

II

\section{Alternative Conceptions of Discrimination}

In this Part, we illustrate competing meanings of nondiscrimination with respect to investigative decisionmaking, the use of force, and sentencing.

\section{A. Racial Profiling}

Consider three criteria of equal treatment in investigative decisionmaking: the likelihood that an innocent person will be investigated, the likelihood that a guilty person will be apprehended, and the Iikelihood that a stop or search will uncover evidence of wrongdoing. ${ }^{47}$ If group crime rates differ substantially across groups, it may be impossible to simultaneously eliminate racial disparities in each of these outcomes. Given that the campaign against racial profiling arose largely in response to the disproportionate investigation of innocent minority motorists, one might decide to decrease the rate of investigation of Blacks, so that innocent Blacks would be no more likely to be investigated than innocent Whites.

Reducing the stop-search rate of Blacks might equalize the likelihood that an innocent person would be investigated, but it would also decrease

44. African Americans constitute $12.8 \%$ of the U.S. population. U.S. Census Bureau, Annual Estimates of the Population by Sex, Race and Hispanic or Latino Origin for the United States: April 1, 2000 to July 1, 2004 (2006), available at http://www.census.gov/popest/national/asrh/NC-EST2004srh.html (last visited Apr. 28, 2006). Approximately 14\% of males fifteen to twenty-four years old (a group that commits a disproportionate amount of street crime) are African American. See U.S. Census Bureau, Male Population by Age, Race and Hispanic or Latino Origin for the United States: 2000, available at http://www.census.gov/population/cen2000/phc-t9/tab02.pdf (last visited May 19, 2006).

45. According to the U.S. Department of Justice Statistics, in 2004 African Americans were arrested for $47.2 \%$ of murders, $53.3 \%$ of robberies, $32.7 \%$ of assaults, and $31.9 \%$ of rapes. Federal Bureau of Investigation, U.S. Department of Justice, Crime in the United States 2004 298, tbl.43 (2005).

46. Banks, supra note 5, at 582-82.

47. If an innocent person's likelihood of being stopped does not depend on his race, then innocent Whites and Blacks are being treated equally. Guilty Afriean Americans and Whites would be treated equally if a Black perpetrator is no more or less likely than a White perpetrator to be apprehended. Under the third criterion, the equal treatment principle would be satisfied if stops of Blacks are as likely as stops of Whites to yield evidence of wrongdoing. For a finer grained discussion of this issue, see Banks, supra note 5. 
the likelihood that guilty Blacks will be apprehended. ${ }^{48}$ If the crime rate is higher among Blacks than Whites, but the rates of investigation are the same, then an African American criminal will be less likely to be apprehended than a White criminal. ${ }^{49}$ To equalize across groups the likelihood that a criminal will be apprehended would require increasing stop-search rates among Blacks, which would have the unfortunate consequence of also increasing the likelihood that innocent Blacks are investigated. Additional stops or searches would ensnare more of the guilty, but also burden more of the innocent. More generally, the basic dilemma is that one cannot attain equality across groups with respect to both the investigation of the innocent and the apprehension of the guilty. Either innocent members of the higher crime rate group will be subject to a greater likelihood of investigation, or a greater percentage of criminals from the higher crime rate group will be permitted to remain at large.

The calculus becomes even more complicated in light of the fact that equal treatment could also be defined in terms of either the level of crime or the social consequences of crime. In this view, the equal treatment principle would be violated either if law-abiding African Americans are burdened by more criminal wrongdoing than are Whites, or if the social harms of crime are greater in African American communities-perhaps because those communities are already disadvantaged - than in White communities.

These additional formulations of the equal treatment principle underscore the inevitability of tradeoffs when crime rates differ substantially across groups and most crime is intra-racial. Apprehending the same percentage of wrongdoers in each group, for example, would leave more Black criminals than White criminals at large as a proportion of each group's population, ${ }^{50}$ and would leave law-abiding African Americans subject to more crime than law-abiding Whites.

This simple example underscores our central point: enforcing the nondiscrimination mandate in our racially stratified society often entails choosing among disparities. The various formulations of equal treatment are in tension and cannot all be realized. Thus, one must choose among them, which requires evaluating the costs and benefits, both for particular groups and for society as a whole, of the various sets of outcomes. ${ }^{51}$

48. The equalization of stop-search rates might also cause accuracy rates to diverge. See Jeff Dominitz, How Do the Laws of Probability Constrain Legislative and Judicial Efforts to Stop Racial Profiling?, 5 Am. L. \& ECON. REv. 412 (2003).

49. A disparity across groups in the percentage of wrongdoers apprehended could be viewed as unfair to either group. Not only might law-abiding members of the high crime rate group assert a claim of unfaimess, but perhaps so too could criminal perpetrators from the low crime rate group, who would face a higher likelihood of apprehension than their high crime rate group peers. See Albert W. Alschuler, Racial Profiling and the Constitution, U. CHI. LEGAL F. 163, 223 (2002).

50. See Amy Farmer \& Dek Terrell, Crime Versus Justice: Is There a Trade-Off?, 44 J.L. \& ECON. 345 (2001).

51. Banks, supra note 5 , at 586-87. 


\section{B. Shooting Behavior}

The findings of the shooting behavior studies further highlight the difficulty of simultaneously realizing alternative conceptions of equal treatment. Recall that research participants (some of whom were police officers) were more likely to "shoot" unarmed Black suspects than unarmed White suspects, and more likely to "not shoot" armed White suspects than armed Black ones. ${ }^{52}$ The claim of unequal treatment is plain: unarmed Blacks were more likely to be shot than unarmed Whites, which might plausibly suggest that the lives of innocent Blacks were valued less than the lives of innocent Whites. These findings comport with Bureau of Justice Statistics data that Blacks are four times as likely as Whites to be killed by police. ${ }^{53}$

In the shooter bias studies, race is unrelated to the likelihood that a suspect is armed ${ }^{54}$ Data compiled by the Bureau of Justice Statistics, however, put into question whether that experimental condition reflects the circumstances that police officers actually confront. Blacks are not only overrepresented as victims of police violence, they are also overrepresented as perpetrators of violence against police. ${ }^{55}$ While Blacks are four times more likely than Whites to be killed by police, police officers are also five times more likely to be killed by a Black person than by a White person. ${ }^{56}$

If race is associated with the likelihood that a suspect is armed, ${ }^{57}$ eliminating the disproportionate shooting of unarmed Blacks might produce a racial disparity in the likelihood that an officer would be shot by an armed suspect. More generally, equalizing the probability across races of shooting an unarmed suspect could preclude equalizing the probability of failing to shoot an armed suspect..$^{58}$ Evaluating shooting outcomes would

52. More generally, there are two types of potential errors - one is to shoot an unarmed suspect; the other is not to shoot an armed suspect-the frequency of which is likely inversely related. Fewer shootings of unarmed suspects, for example, could be achieved at the price of more failures to shoot armed suspects and, presumably, more dead police officers. In some studies the joint probability of an error was nominally greater for White suspects, see, e.g., Correll et al., supra note 19; and Plant et al., supra note 19 . In other studies the joint probability of error was nominally greater for Black suspects. See Plant \& Peruche, supra note 19.

53. Brown \& Langan, supra note 17 , at 26.

54. Studies conducted by Plant and colleagues attempted both to document the so-called shooter bias and to reduce or eliminate it through training. Using the same videogame format as Correll, Plant found that "although the participants were initially more likely to mistakenly shoot unarmed Black suspects than unarmed White suspects, after extensive practice with the program, in which the race of the suspect was unrelated to the presence of a weapon, this racial bias was eliminated both immediately and 24 br. later." See Plant \& Peruche, supra note 19.

55. Brown \& Langan, supra note 17.

56. Id. at 26 .

57. Throughout this discussion, references to the likelihood that a suspect is armed also include the likelihood that a suspect would use his or her weapon to avoid arrest.

58. Moreover, it could be the case that the best way to minimize the joint probability of any innocent person being shot and of any law enforcement officer being shot would be to employ a different shooting criterion for Blacks than for Whites. The decision to select a baseline that minimizes 
require not only deciding how to balance the goals of protecting the lives of innocent suspects and of police officers, but also deciding how to balance protecting the lives of innocent Whites as opposed to innocent Blacks.

\section{Sentencing}

The sort of tradeoffs we have been describing are both salient and familiar in connection with capital sentencing, where research has consistently found that killers of Whites are more likely to be sentenced to death than are killers of Blacks. ${ }^{59}$ Because most homicides are intra-racial, eliminating the race-of-victim disparity-either through executing inore murderers of Blacks or fewer murderers of Whites-would create or exacerbate a race-of-defendant disparity. ${ }^{60}$ The same dilemma would arise, of course, had the researchers initially found a sentencing disparity based on the race of the defendant rather than the race of the victim.

As with the race-of-defendant and race-of-victim disparities, eliminating stereotypicality discrimination in sentencing could produce a racial disparity in intergroup outcomes. Recall that Eberhardt and colleagues found that Black defendants' racial stereotypicality influenced their likelihood of being sentenced to death only when their victims were White. ${ }^{61}$ Eliminating stereotypicality discrimination through executing fewer high stereotypicality Blacks would diminish the race-of-victim disparity. Alternatively, executing more low stereotypically Black defendants would exacerbate the race of the victim disparity. In either case, a race-of-defendant disparity would emerge if there had not been one previously. Similarly, eliminating the stereotypicality disparity that Blair uncovers only among White defendants would yield a race-of-defendant disparity. Eliminating such stereotypicality discrimination through lessening the sentence severity of some White defendants, for example, would result in Black defendants, as a group, receiving harsher penalties than White defendants. ${ }^{62}$

The studies reviewed above examine discrimination in the domain of criminal justice. In the next Part, we consider the study of implicit bias.

both types of error would conflict with the principle of raceblind decisionmaking if race is associated with the likelihood that a suspect is armed, and if decisionmaking is more accurate when race is taken into account than when it is not.

59. U.S. Gen. Acct. Off., supra note 26.

60. This tradeoff has been discussed, most famously, in connection with the empirical data the Supreme Court confronted in McCleskey v. Kemp, 481 U.S. 279 (1987). See, e.g., Randall L. Kennedy, McCleskey v. Kemp: Race, Capital Punishment, and the Supreme Court, 101 Harv. L. Rev. 1388 (1988).

61. Eberhardt et al., supra note 29.

62. In this case, the antidiscrimination norm would benefit the group viewcd as the historical beneficiary rather than as the victim of discrimination. For a similar use of antidiscrimination in the gender context, see, e.g., Miss. Univ. for Women v. Hogan, 458 U.S. 718 (1982). 
III

\section{Alternative Conceptions of Bias}

In this Part, we use the Race IAT to consider the question of the meaning of racial bias in a society that has disavowed racism, yet remains racially unequal.

\section{A. The Implicit Association Test}

When social scientists began to measure racial bias in the early decades of the twentieth century, they focused on attitudes and beliefs that people consciously hold and explicitly endorse. ${ }^{63}$ Racial bias, as reflected in such conventional measures, has declined precipitously since then, as changing social norms have stigmatized racism as morally repugnant. ${ }^{64}$ However, it is difficult to know whether the apparent decline in bias reflects simply people's unwillingness to voice sentiments that they continue to hold but know are socially disfavored, or their lack of awareness of their own bias. In response to these possibilities, social psychological researchers in recent years have developed a number of less obtrusive or indirect measures of racial bias. ${ }^{65}$

Perhaps the best known and most widely publicized of such measures is the Implicit Association Test (IAT), ${ }^{66}$ a methodologically rigorous, computer administered test that now can be taken over the internet. The IAT is intended to uncover "implicit bias" by measuring the strength of the association between social categories (e.g., Blacks or Whites) and positive and negative attributes (e.g., "joy" and "love" versus "agony" and "evil"). Although separate IATs have been developed with respect to many different traits (e.g., sex, age, nationality, weight, political affiliation, and sexual orientation), ${ }^{67}$ the form of the IAT that has attracted the most attention is the Race IAT, ${ }^{68}$ which has been taken by more than four million people. ${ }^{69}$

63. See Gordon W. Allport, Attitudes, in A Handbook of Social Psychology 798 (Carl Murcheson ed., 1935); Daniel Katz \& Kenneth W. Braly, Racial Prejudice and Racial Stereotypes, 30 J. Abnormal \& Soc. Psychol. 175 (1935); Daniel Katz \& Kenneth W. Braly, Racial Stereotypes of One Hundred College Students, 28 J. ABnormal \& Soc. Psychol. 280 (1933).

64. Devine \& Elliot, supra note 8; John F. Dovidio \& Samuel L. Gaertner, Prejudice, Discrimination, and Racism: Historical Trends and Contemporary Approaches, in Prejudice, Discrimina tion, ANd Racism 1 (John F. Dovidio \& Samuel L. Gaertner eds., 1986).

65. See Russell H. Fazio \& Michael A. Olson, Implicit Measures in Social Cognition Research: Their Meaning and Use, 54 ANN. REV. PsYCHOL. 297 (2003) (reviewing a range of methods for measuring implicit bias).

66. Anthony G. Greenwald et al., Measuring Individual Differences in Implicit Cognition: The Implicit Association Test, 74 J. Personality \& Soc. Psychol. 1464 (1998). The IAT has received a substantial amount of publicity in the popular press. See, e.g., Don't Race to Judgment, U.S. News \& WORLD REP., .Dec. 26, 2005, at 90, available at http://www.usnews.com/usnews/health/articles/ 051226/26spirit.race.htm; Shankar Vedantam, See No Bias, WASH. Post, Jan. 23, 2005, at W12.

67. See, e.g., Rainer Banse et al, Implicit Attitudes Towards Homosexuality: Reliability, Validity, and Controllability of the lAT, 48 ZeitsChrift Fur EXPerimentelle Psychologie 145 (2001); Greenwald et al., supra note 66 (utilizing the IAT to measure differences between Japanese Americans 
The Race IAT requires the participant to sort images or words that appear on a computer screen as quickly as possible into either of two categories. ${ }^{70}$ Each category consists of the pairing of a racial group and a positive or negative attribute. In one iteration, the negative attribute would be paired with Blacks, and the positive attribute with Whites. ${ }^{71}$ As words appear on the computer screen, the participant is instructed to indicate as quickly as possible, by pressing specific buttons on the keyboard, whether the word belongs to the Black-negative pairing or the White-positive pairing. In the next iteration, the pairings are reversed (i.e., in our example, Black would be paired with the positive attribute and White with the negative one), and participants are again instructed to assign new words as quickly as possible to one pairing or the other. ${ }^{72}$

The difference in response time in these two conditions is the measure of implicit bias. If a participant more quickly sorts images and words when Black is paired with the negative attribute and White with the positive attribute (compared to when the pairings are reversed), then the participant is said to have an implicit bias against African Americans. ${ }^{73}$ The majority of participants sort words and images faster when White is paired with the positive attribute, and Black with the negative attribute. ${ }^{74}$ The majority of participants are thus said to have an implicit bias against African Americans. ${ }^{75}$ For the findings of the IAT to be viewed as a measure of bias, however, requires a definition of bias.

and Korean Americans in their evaluative associations toward Japanese and Korean ethnic groups); Becca R. Levy \& Mahzarin R. Banaji, Implicit Ageism, in Ageism: Stereotyping and Prejudice Against Older Persons (Todd D. Nelson ed., 2002); Brian A. Nosek et al., Harvesting Implicit Group Attitudes and Beliefs from a Demonstration Web Site, 6 Group DYNAMICS: THEORY, RESEARCH, AND PRACTICE 101 (2002) (reporting results from race, age, gender, and political affiliation 1ATs).

68. See Fazio \& Olson, supra note 65 , at 307-08 (describing various 1ATs).

69. Don't Race to Judgment, supra note 66.

70. See Jerry Kang, Trojan Horses of Race, 118 HaRv. L. Rev. 1489, 1510 (2005); Greenwald et al, supra note 66 .

71. In the actual Race IAT test, the formal race category labels "African American" and "European American" are used instead of "Black" and "White," as the latter labels conjure associations with "good" and "bad" independent of race. Such associations could confound measurements of bias in the test. Anthony G. Greenwald \& Linda Hamilton Krieger, Implicit Bias: Scientific Foundations, 94 CALIF. L. Rev. 945, 952 (2006).

72. The 1AT is methodologically rigorous. The order of the pairings, for example, is randomized across test administrations. For a discussion of the methodological soundness of the 1AT, see Kang, supra note 70 , at 1510 .

73. If the participant sorts words and images equally quickly irrespective of which racial group is associated with which attribute, then the participant is said not to have an implicit bias. And finally, of course, if the participant more quickly sorts images and words when the pairings are White-negative and Black-positive, then the participant is said to have an implicit bias against Whites.

74. See Greenwald \& Krieger, supra note 71, at 958, tbl.2.

75. See Greenwald \& Krieger, supra note 71, at 958, tbl.2. Note, however, that while any nonAfrican American racial group in the United States has a significant number of persons with an implicit bias against African Americans, African Americans themselves do not show substantial implicit bias in a particular direction. According to data gathered from the Project Implicit website, $71.5 \%$ of White participants favor European Americans, whereas only $32.4 \%$ of Black participants favor European 


\section{B. "Bias" and Race Blindness}

A common starting point for thinking about racial bias might be that it involves perceiving or thinking differently of someone on the basis of race. An unbiased person, in this view, would accord race no more significance than, say, eye or hair color, and would behave as though one does not notice race. ${ }^{76}$

However appealing this conception of bias may seem in the abstract, most people do not really believe that according race any more significance than eye or hair color necessarily constitutes bias. The centrality of race to our history and the substantial racial inequalities that continue to pervade society render race an extraordinarily salient and meaningful social category. A generation after the civil rights movement, African Americans remain segregated, ${ }^{77}$ and disadvantaged relative to Whites with respect to employment, earnings and assets, educational achievement and attainment, and health and longevity. ${ }^{78}$ The average White family earns 1.5 times as much income, ${ }^{79}$ and has several times as much wealth, as the average Black family ${ }^{80}$ Additionally, African Americans are more than twice as likely as Whites to be unemployed. ${ }^{81}$ In fact, in 1996, Black male high school dropouts aged twenty to thirty-five were more likely to be in prison than employed. ${ }^{82}$ The race gap in educational achievement is substantial as well. ${ }^{83}$

The significance of these pervasive inequalities is reflected in our actual intuitions about bias. Even those who laud the ideal of race blindness would admit, if pressed, that in our society one need not, and perhaps cannot, be blind to race.$^{84}$ Most of us believe that it is proper, desirable even,

Americans. Moreover, $33.4 \%$ of Black participants favor African Americans, and $33.6 \%$ show no preference for either racial group. Id.

76. See R. Richard Banks, "Nondiscriminatory" Perpetuation of Racial Subordination, 76 B.U. L. REV. 669 (1996); Banks, supra note 6.

77. See Douglas S. Massey \& Nancy A. Denton, American Apartheid: Segregation and the Making of the Underclass (1993); Gary Orfield et al., Losing Our Future: How Minority Youth Are Being Left Behind by the Graduation Rate Crisis (2004); Social Stratification: Class, Race, and Gender in Sociological Perspective (David Grusky ed., $2 \mathrm{~d}$ ed. 2001).

78. White men can expect to live, on average, more than six years longer than Black men. The average life expectancy for White men is 75.1 years, and for Black men 68.8 years. U.S. Census Bureau, Statistical Abstract of the United States 78, tb1.98 (2006). Black infants are 2.5 times more likely than White infants to die within a year of birth. $I d$.

79. U.S. Census Bureau, supra note 78 , at 460 , tbl.673. The averagc White family eamed $\$ 45,631$ in 2003 , while the average Black family earned $\$ 29,645$.

80. Id.

81. Id. at 409 , tbl.610 (2006).

82. Bruce Westem, The Impact of Incarceration on Wage Mobility and Inequality, 67 AM. Soc. REV. 526 (2002).

83. See, e.g., Ronald F. Ferguson, Test-Score Trends Along Racial Lines, I97I to 1996: Popular Culture and Community Academic Standards, in America Becoming: Racial Trends and Their CONSEQuences (Neil J. Smelser et al. eds., 2001).

84. The decision to east a White actor in a theatrical or movie role, for example, is not viewed by most people as racist. Russell K. Robinson, Casting and Caste-ing: Reconciling Artistic Freedom and 
to pay some attention to race, even in ways that burden racial minorities. lndeed, some commentators have argued that not noticing race, or acting as though race does not matter, is itself a form of racial bias. ${ }^{85}$

In the criminal justice context alone there are many instances where private citizens and public officials alike act in a race conscious fashion and yet are not viewed as racially biased. The crime victim who notices the race of an assailant, and the police officer who only stops people of the same race as the assailant are not viewed as having engaged in racial discrimination. Equal protection doctrine reflects these intuitions: no court has ever found a law enforcement officer's decision to stop individuals of one race rather than another racially discriminatory if the officer does so because he is seeking a specific criminal suspect of that race. ${ }^{86}$ Indeed, virtually no scholar or court has seriously considered the possibility that either private citizens or law enforcement officers should act as though they are blind to the race of specific criminal assailants or accord race no more weight than any other observable characteristic. ${ }^{87}$

So, the distinction between being racially biased and racially unbiased cannot be a distinction between race blindness and race consciousness, or between according race significance and not, for everyone is race conscious and vests race with more meaning than physical characteristics such as eye or hair color. On this view, if the findings of the Race IAT constitute evidence of racial bias it cannot be because they confirm that people deviate from some ideal of being (nearly) blind to race.

\section{Bias and Race Consciousness}

So when we decide whether something is racially biased we are drawing distinctions among psychological states that are all, at some level, race conscious. We might designate a race conscious psychological state as biased if it is sufficiently similar to paradigmatic forms of bias or if it causes racial discrimination.

\section{A Similarity-Based Determination}

One way of deciding whether a particular psychological state should be viewed as biased would be to compare it to states of mind that are universally regarded as racist. An irrational animus toward or dislike of an entire group, a broadly applied and invariant stereotype that is resistant to refutation, a belief that some fundamental or inherent difference marks

\footnotetext{
Antidiscrimination Norms, 95 CALIF. L. REv. (forthcoming 2007). Nor would the intentional use of race in an advertisement be viewed as necessarily racist.

85. Juan Perea, Thinking About Race and Races: Reflections and Responses, 89 CaLIF. L. REv. 1653 (2001).

86. See Banks, supra note 6, at 1077, 1081-82.

87. Id.
} 
some groups as inferior to others-such views are paradigmatic instances of racism. ${ }^{88}$ The more similar the new case to these paradigmatic cases, the greater the warrant for the designation "bias." 89 Yet such similarity-based judgments are far from objective. Rather than merely cataloguing features, similarity judgments entail the selection of some features as more fundamental than others, ${ }^{90}$ a calculus that invariably relies on some implicit account of what makes something what it is. ${ }^{91}$ With respect to racial bias, this is precisely the sort of question about which views differ.

Controversy regarding the Race 1AT aptly illustrates this sort of disagreement. ${ }^{92}$ Some researchers assert that Race IAT scores do not signify bias because they measure one's knowledge of racial stereotypes and prejudices that are prevalent in society, and do not imply that one endorses those beliefs and attitudes. ${ }^{93}$ Other researchers counter that one need not endorse an attitude or stereotype for it to warrant the designation "racial bias." 94 These researchers may disagree about whether the Race 1AT measures bias partly because they disagree about the nature of bias. Is an unfavorable stereotype an instance of bias only if one endorses it? Does bias refer only to attitudes or beliefs that are irrational $?^{95}$ Or only those beliefs that are either conscious or resistant to change $?^{96}$ While commentators may interpret the empirical evidence differently, they may also conceptualize bias differently, in which case the disagreement would likely not be resolved by further methodological refinement. Precisely because the

88. See, e.g., Gordon W. Allport, The Nature of Prejudice 17 (1954).

89. Such similarity based judgments are characteristic of reasoning about many categories. See Douglas L. Medin, Concepts and Conceptual Structure, 44 AM. Psychologist 1469 (1989); Douglas L. Medin et al., Respects for Similarity, 100 PsyCHOL. REV. 254 (1993).

90. Id.

91. Id.

92. See Hal R. Arkes \& Philip E. Tetlock, Attributions of Implicit Prejudice, or "Would Jesse Jackson 'Fail' the Implicit Association Test?", 15 Psychol. INQuIRY 257 (2004); see also Andrew Karpinski \& James L. Hilton, Attitudes and the Implicit Association Test, 81 J. Personality \& SoC. Psychol. 774 (2001); Philip E. Tetlock \& Hal R. Arkcs, The Implicit Prejudice Exchange: Islands of Consensus in a Sea of Controversy, 15 PSYCHOL. INQUIRY 311 (2004).

93. See, e.g., Arkes \& Tetlock, supra note 92; Michael A. Olson \& Russell H. Fazio, Reducing the Influence of Extrapersonal Associations on the Implicit Association Test: Personalizing the IAT, 86 J. Personality \& Soc. Psychol. 653 (2004); Andrew Karpinski \& James L. Hilton, Attitudes and the Implicit Association Test, 81 J. Personality \& Soc. Psychol. 774 (2001).

94. See Arkes \& Tetlock, supra note 92 at 260-61; Bruce Bower, The Bias Finders: A Test of Unconscious Attitudes Polarizes Psychologists, Scl. News Online, Apr. 22, 2006, available at http://www.sciencenews.org/articles/20060422/bob9.asp.

95. Economists, for example, sometimes tend to view rational statistical discrimination as unworthy of the condemnation accorded animus or taste hased discrimination. See, e.g., John Knowles, Nicola Persico \& Petra Todd, Racial Bias in Motor Vehicle Searches: Theory and Evidence, $109 \mathrm{~J}$. Pol. ECON. 203 (2001).

96. This position is arguably reflected in the Supreme Court's Equal Protection Clause jurisprudence. While the Supreme Court has never said that unintentional discrimination is exempt from the nondiscrimination mandate of the Equal Protection Clause or of federal statutes, the Court has stated that "Proof of a discriminatory intent or purpose is required to show a violation of the equal protection clause." Vill. of Arlington Heights v. Metro. House. Dev. Corp., 429 U.S. 252, 265 (1977). 
identification of bias entails conceptual and normative judgment, it will reflect differences in individual values that may be irreconcilable.

\section{A Behavior-Based Determination}

One way out of this conceptual morass would be to declare simply that a mental state signifies bias if it consistently produces discrimination against African Americans. In this view, if implicit bias against African Americans, as measured by the IAT, predicts discrimination against African Americans, then Race IAT scores would signify a form of racial bias. ${ }^{97}$ This is a reasonable approach. Explicit measures of bias do not powerfully predict discrimination. Nor is implicit bias, as measured by the IAT, highly correlated with explicit bias. ${ }^{98}$ So maybe discrimination, of the sort evident in the shooting studies for example, could be predicted by implicit bias. ${ }^{99}$

Thus far, however, there is little evidence that Race IAT scores correlate with discrimination against African Americans. Most of the race-crime research has not yet incorporated an IAT measure. The one study we discuss that attempted to correlate IAT scores with shooting behavior did not find a statistically significant relationship between the two. ${ }^{100}$

Beyond the domain of race and crime, evidence linking IAT scores and racially discriminatory behavior is similarly sparse. The few published studies that have found a statistically significant relationship between participants' Race IAT scores and their performance in a study concern aspects of one's demeanor that are both subtle and ambiguous (e.g., eye contact, speech errors, and facial expression). ${ }^{101}$ While such physical cues

97. We do not mean to suggest, though, that a belief or attitude is not a form of bias unless it influences behavior. The causal link between attitudes and beliefs on one hand and behavior on the other is weaker than commonly supposed.

98. See Fazio \& Olson, supra note 65, at 303 ("Within the domain of prejudice and stereotypes, the correlations [of implicit and explicit bias] tend to be quite low . . . although there are occasional reports of significant correlations.").

99. Greenwald \& Krieger, supra note 71 , at 966.

100. Greenwald et al., supra note 19. In addition to completing a shooter-bias task, participants were given tests measuring both implicit and explicit race prejudice. No correlation was found between the results of the shooting task and the implicit and explicit measures of bias. Id. at $400 \mathrm{n} .3$.

101. See, e.g., Allen R. McConnell \& Jill M. Leibold, Relations Among the Implicit Association Test, Discriminatory Behavior, and Explicit Measures of Racial Attitudes, 37 J. ExPERImental Soc. PSYCHOL. 435 (2001) (finding that participants with IAT scores indicating a bias in favor of Whites made fewer speech errors, hesitated less, and were more friendly toward a White experimenter than they were toward a Black experimenter); see also Leslie Ashburn-Nardo et al., Black Americans' Implicit Racial Associations and Their Implications for Intergroup Judgment, 2I Soc. CogNITION 61 (2003) (finding that the more Black participants preferred their own race over Whites, as measured by the IAT, the greater their preference for a Black partner relative to a White partmer on an intellectually challenging activity); Kurt Hugenberg \& Galen V. Bodenhausen, Ambiguity in Social Categorization: The Role of Prejudice and Facial Affect in Race Categorization, 15 PsYcHOL. Scl. 342 (2004) (finding that participants high in implicit prejudice-as measured by the IAT-were more likely to categorize racially ambiguous faces as African American when the faces displayed hostile or angry expressions); Kurt Hugenberg \& Galen V. Bodenhausen, Facing Prejudice: Implicit Prejudice and the Perception of Facial Threat, 14 PsYCHOL. SCI. 640 (2003) (finding that higher implicit bias against 
may be socially consequential, ${ }^{102}$ they are probably not what most people think of when they think of discriminatory behavior. Such aspects of demeanor might also be consistent with any of a number of psychological states. A White person might make less eye contact with a Black person than a White person because he dislikes or devalues Black people, because he fears being perceived as a racist, ${ }^{103}$ or because he feels more comfortable with other White people. It is difficult to characterize such subtle "behaviors" as biased in the absence of information about their psychological antecedent. ${ }^{104}$ A disinclination to make eye contact would reflect bias if prompted by group animus or negative stereotypes, but probably not if prompted by fear of oneself being negatively perceived or evaluated. And views might differ as to whether comfort with one's own racial group is necessarily racist. If eye contact, speech errors, and facial expression can only be condemned as discriminatory behavior based on suppositions about the psychological state that produced them, then such "behaviors" cannot be used as the basis for deciding whether the Race IAT measures bias. In sum, the behavioral approach does not resolve the question of whether Race 1AT scores constitute bias because the promise of the IAT as a predictor of unquestionably racially discriminatory behavior has yet to be realized. ${ }^{105}$

The difficulty in deciding whether Race IAT scores signify racial bias is part of a broader disagreement about the meaning of racial bias and discrimination. Consider, for example, the sentencing studies by Eberhardt and by Blair, both of which found that the more stereotypically Black a defendant appeared, the more likely he was to receive a harsh sentence. ${ }^{106}$

African Americans was associated with a greater readiness to perceive anger in Black faees). Jennifer Richeson, Nicole Shelton and colleagues found that White participants with higher IAT scores were impaired on a Stroop test following interaction with a Black individual. The researchers also used an fMRI technique to examine the neurological correlates of this effect. Jennifer A. Richeson \& J. Nicole Shelton, When Prejudice Does Not Pay: Effects of Interracial Contact on Executive Function, 14 Psychol. SCI. 287 (2003); Jennifer A. Richeson et al., An fMRI Investigation of the Impact of Interracial Contact on Executive Function, 6 NATURE NeURoscienCE I323 (2003).

102. See Carl O. Word et aI., The Nonverbal Mediation of Self-Fulfilling Prophecies in Interracial Interaction, 10 J. EXPerimental Soc. PSyChoL. 109 (1974).

103. See, e.g., Patricia G. Devine \& Kristin A. Vasquez, The Rocky Road to Positive Intergroup Relations, in Confronting Racism: The Problem and the Response 234 (Jennifer L. Eberhardt \& Susan T. Fiske eds., 1998); Jacquie D. Vorauer \& Cory A. Turpie, Disruptive Effects of Vigilance on Dominant Group Members' Treatment of Outgroup Members: Choking versus Shining Under Pressure, 87 J. Personality \& Soc. Psychol. 384 (2004).

104. The rhetorical relationship between bias and discrimination is bidirectional. Identifying a discriminatory behavior inclines one to view its psychological correlate as a form of bias, and conversely, identifying a psychological state as biased bolsters the condemnation of a discriminatory behavior.

105. To date, there are no published studies that have found a statistically significant relationship between Race IAT scores and the sort of discrimination against African Americans that would constitute disparate treatment in violation of the law. See, e.g., T. Andrew Poehlman, Eric L. Uhlmann, Anthony G. Greenwald, \& Mahzarin R. Banaji, Understanding and Using the 1mplicit Association Test: III. Meta-analysis of Predictive Validity (unpublished manuscript).

106. See Blair et al., supra note 29, at 675; Eberhardt et al., supra note 29 at 384. 
Whereas Eberhardt found that stereotypicality discrimination operated against Blacks convicted of murdering White victims, ${ }^{107}$ Blair found that Whites who looked more stereotypically Black received harsher sentences than Whites who looked less so. ${ }^{108}$ People might disagree about whether such stereotypicality discrimination should count as racial discrimination and, by extension, whether the psychological state that animates such discrimination should count as racially biased. If a juror treats Whites and Blacks equally as a group, but disfavors Blacks who appear most stereotypically Black, has that juror manifested racial bias? And if one views stereotypicality discrimination against some Black murderers of White victims as racially biased, would the same judgment apply to Blair's findings, ${ }^{109}$ where only White defendants' sentences were found to depend on how stereotypically Black they appeared? ${ }^{110}$

Ultimately, what constitutes bias depends, quite simply, on how we choose to conceptualize it. In a society as racially unequal as ours, in which to be unbiased cannot require something akin to race blindness, the question of what should count as racial bias is itself contestable.

\section{CONCLUSION}

In this first decade of the twenty-first century, we often talk as though we have developed a consensus opposition to racial bias and to discrimination that burdens racial minorities. The simplest and most straightforward account of the normative consensus is that bias and discrimination are wrong and should be eliminated. Our primary goal in this Article has been to show that this consensus is imperiled by the racial inequality that pervades our society. The apparent consensus operates at a high level of generality and fractures as one applies it to concrete cases in our racially stratified society. We have renounced racial bias, but we have yet to agree what constitutes racial bias. We oppose discrimination in the criminal justice system, but we may havc very different ideas about what nondiscrimination would look like. The terms bias and discrimination are thus

107. They hypothesize that this is because the mixed character of such cases highlights the salience of race, and perhaps makes the case seem a matter of intergroup conflict, rather than interpersonal conflict (as with a same-race case).

108. The Blair study found a statistically significant relationship (after controlling for a number of nonracial factors associated with severity of punishment) between Afrocentric features and sentence length. However, as the authors acknowledge in a footnote, treating the Black and White samples separately revealed that the Afrocentric features and sentence length relationship was statistically significant for White defendants, but not for Black defendants. See Blair et al., supra note 29, at 675 .

109. Blair et al., supra note 29.

110. Blair and colleagues described their findings as evidence of a "pernicious" process contrary to the state of Florida's "demonstratcd commitment to race neutrality in sentencing." Id. They concluded that "Be they White or Black, offenders who possess more Afrocentric features are receiving harsher sentences for the same crimes, compared with less Afroccntric-looking offenders." Id. at 678 . See also William T. Pizzi, Irene V. Blair \& Charles M. Judd, Discrimination in Sentencing on the Basis of Afrocentric Features, 10 MiCH. J. RACE \& L. 327 (2005). 
much more indeterminate than lay, and scholarly, discourse often presuppose.

The indeterminacy of these terms undermines their analytical usefulness. An abstract commitment to antidiscrimination and antibias principles will, all too often, fail to resolve a concrete policy question or dictate a moral stance toward a particular race conscious state of mind. One means of better grappling with questions of racial fairness that arise in the criminal justice system would be to evaluate directly the harms and benefits associated with particular outcomes. This approach could help to realize the substantive values that animate the antidiscrimination principle, even as it would, ironically, deemphasize the question of whether any decision-maker acted on the basis of race. Whatever the analytical benefits of such a more policy-oriented approach, its ideological consequences would need to be considered as well. Popular understanding of the antidiscrimination and antibias principles may obscure substantive disagreement, but it also has made much useful political action possible. Our central claim then is not normative so much as descriptive: The ascendance of the antidiscrimination principle and the disavowal of racism have relocated rather than resolved disagreement about the meaning of racial equality in this first decade of the twenty-first century. 